\title{
iaspm@journal
}

ISSN 2079-3871

\section{Beyond Authenticity, Beyond Romanticism: Films about Maanam}

\author{
Ewa Mazierska \\ University of Central Lancashire \\ EHMazierska@uclan.ac.uk
}

\begin{abstract}
This article examines two Polish films from the 1980s, Wielka majówka ("The Big Picnic", 1981) directed by Krzysztof Rogulski and Czuje się świetnie ("I Feel Great", 1984) directed by Waldemar Szarek, which cast Maanam, one of the most popular Polish bands of that period. I present these films in the context of a dominant representation of artists in Eastern European cinema and of Polish Romanticism, which endows artists with a specific role, arguing that this approach is to some extent different to what we typically observe in western biopics. Together, these two films show that while in the 1980s filmmakers in Poland recognized the commercial potential of using rock music and rock stars in films, they were not fully aware of the advantages of making biopics according to the western formula or did not care about these advantages.
\end{abstract}

KEYWORDS: Maanam, Polish Rock, Biopic, Polish Film, Romanticism, Authenticity

\section{Introduction}

Maanam, along with Perfect, Republika and Lady Pank, was one of the most popular Polish rock bands of the 1980s and its lead singer, Kora, still occupies the position of one of the greatest Polish female rock stars. A testimony to Maanam's renown is the attention devoted to them by filmmakers. They took part in several fiction and documentary films and their music was used in the soundtracks of at least ten films, such as Sezon na bażanty ("Pheasant-shooting Season", 1986), directed by Wiesław Saniewski and Bohater roku ("Hero of the Year", 1987), directed by Feliks Falk. In this chapter I focus on two

IASPM@Journal vol.7 no.1 (2017)

Journal of the International Association for the Study of Popular Music

ISSN 2079-3871 I DOI 10.5429/2079-3871(2017)v7i1.5en I www.iaspmjournal.net 
productions from their heyday, Wielka majówka ("The Big Picnic", 1981), directed by Krzysztof Rogulski and Czuję się świetnie ("I Feel Great", 1984), directed by Waldemar Szarek. These films conform to the (probably most liberal) definition of pop-rock biopic: a "film which purports to tell, in part or in full, the biography of a musical performer (living or dead) and which contains a significant amount of his or her music" (Inglis 2007: 77). However, the amount of biographical detail about Maanam in the first film is minimal and they are not the main characters in the film. Moreover, while we normally associate biopics with films in which actors stand in for the historical figures (Vidal 2014: 3), in Wielka majówka and Czuję się świetnie we see real musicians, yet we are not sure if they play themselves or somebody else. Discussing these films thus allows consideration of the borders of a biopic and local variations of this genre. In my discussion, I will try to establish possible reasons why the directors of these two films neglected these conventions and the principal aim of western biopics, namely telling the truth about their characters. Before I turn to the films, I will take a closer look at the band biography, as it is little known outside Poland, and discuss the way artists were represented in Poland during the period of state socialism and after the collapse of this system.

\section{Maanam's career and style}

Maanam was set up in 1976 as Maanam Elektryczny Prysznic ("Maanam Electric Shower") by Marek Jackowski and Milo Kurtis ${ }^{1}$, both experienced musicians. Soon Kurtis left to set up his own band and Maanam was joined by Englishman John Porter. In 1979 Porter left and in the same year Jackowski's wife, Olga, under the pseudonym Kora, started to perform in Maanam as a singer, which marked a dramatic change in its style. Their appearance at the Krajowy Festiwal Piosenki Polskiej (National Festival of Polish Song) in Opole in 1980, where they performed "Boskie Buenos" ("Divine Buenos"), was a great success. It brought dynamism to Polish rock, which by this point felt timid and conservative. The Jackowskis became the main authors of Maanam's songs: Marek composed music, Kora wrote lyrics.

Maanam was most successful in the first half of the 1980s, a period regarded as the golden age of Polish rock. At the time, which largely coincided with martial law, rock music was an important way for people to express political views. Being denied other means of expression, rock was regarded as either an area of resistance against the weak yet authoritarian state, or as a safety valve, allowing the state to channel the opposition into activities it saw as innocuous (Patton 2011). This period also saw the production of a large number of films about rock music, especially documentaries (Hučková 2015: 405). The two films discussed here belong to this "rock wave". In the late 1980s, when it became clear that state socialism in Poland was doomed, Polish rock lost its privileged position as a tool of political discourse. Its commercial position also diminished at this time, being supplanted by other styles, such as hip hop. 
This narrative refers to Maanam too. In the first half of the 1980s almost every song written by the Jackowskis became a hit and their records sold hundreds of thousands of copies. The band was also constantly touring, giving as many as 300-400 concerts per year (Butrym 1985). Maanam also managed to gain some recognition abroad, particularly in West Germany. In the mid-1980s, at the peak of its popularity, it disbanded. This was caused by factors such as alcoholism and physical exhaustion, as well as the breakdown of the Jackowskis' marriage in 1985. Locating Maanam in relation to international trends requires examining factors such as the character of its music and performances, as well as its position in the Polish market and its relation to the political authorities and official ideology. Maanam's musical style can broadly be defined as punk and post-punk. Punk music in the UK started around 1976, around the same time that Maanam started, although the band turned to punk some years later. There are some musical similarities between Maanam and British punk acts, such as Siouxsie and the Banshees. Like Siouxsie, Kora's voice was very versatile and Maanam's music often had an oriental feel, drawing in Middle Eastern music. Moreover, punk celebrated chaos and a life lived for the moment, and we find the same ideal in many of Maanam's songs, for example "Jest już późno, piszę bzdury" ("It Is Already Late, I'm Writing Nonsense") (O!, Pronit ,1982), where we find the sentence "Wszystko zamyka się w tym jednym dniu jednej chwili" ("Everything is contained in this day and in this moment").

Punk was also the style with which Kora identified herself, forming a close relationship with the audience and promoting an alternative lifestyle (Butrym 1985: 56-57). However, the close relationship with the audience took place only during concerts. In their private lives, the Jackowskis cultivated a certain mystique, particularly around its singer. The fans felt close to Kora not because she was like them, but because she projected their dreams, like a diva rather than a typical punk star.

Kora started her career when she was approaching 30 and she did not look like a typical colourful and scruffy punk star, but came across as minimalistic and neat. On stage she often wore male shirts, leggings and flat shoes, and had very short hair, looking androgynous and other-worldly, and she wore dark glasses that intensified and extended the distance between herself and the audience. Kora performed on stage, as opposed to merely singing, unlike earlier Polish female pop-rock stars, such as Kasia Sobczyk, Karin Stanek or Mira Kubasińska. The sense that she was different from her audience was also transmitted by Kora's lyrics. Unlike Polish pop and rock artists before Maanam, who tended to sing about everyday issues, presented in a direct way, or like Czesław Niemen, who turned to classical poetry to escape from the perceived banality of pop-rock, Kora's lyrics were sophisticated and poetic, yet they worked well only when combined with music. Her mystique was augmented by the widespread knowledge that she had a difficult childhood, spending part of it in an orphanage run by nuns, who mistreated her (Jackowska and Sipowicz 1992: 21-26).

British punk is known for its anti-authoritarian stance: until recently it was seen as the style of a disaffected working class youth (Haenfler 2015: 284-287). Politics features more often in punk's lyrics than in other genres of rock. Maanam also manifested a certain anti- 
authoritarianism, although their lyrics were rarely political and when they were, their criticism of the authorities was subdued. Nevertheless, many of Maanam's songs from the 1980s convey a desire for freedom, which state socialism curtailed by imposing martial law, such as "Stoję, stoję, czuję się świetnie" ("I'm Standing, I'm Standing I Feel Great") (Wifon, 1981). Others subtly ridicule the socialist authorities, as in the song "Nocny Patrol" ("Night Patrol") (Jako/Polton, 1983), which alludes to the police and army patrolling the streets during martial law. However, Maanam did not belong to the punk underground that developed in Poland in the 1980s, as testified by the fact that they made their records (in common with Perfect, Republika and Lady Pank) in state-owned studios and hence their productions were vetted by censors, unlike the unsigned artists associated mainly with punk and new wave scenes (Brzozowicz 2010: 21; Pęczak 2010). This might explain why their criticism of the political system was subdued. That said, on one occasion Maanam also proved insubordinate to the authorities in a more direct way, by refusing to take part in a concert in 1984, celebrating the friendship between Polish and Soviet youth. As a punishment their songs were banned from state radio for six weeks which increased their popularity, as it furnished their persona with an aura of martyrdom (Zieliński 2005: 182).

Other differences between Maanam and British punk point to the different industrial contexts in which representatives of these two styles operated. British punk was not only against the political establishment, but also the musical establishment and large record companies that produced highly professional music perceived to lack critical edge and authenticity, as exemplified by styles such as symphonic and glam rock (Laing 1985: 7). Conversely, Maanam did not distance itself from the profit-oriented music industry. Their ambition was to make records professionally, ideally in the West, where there were better conditions for recording than under the supposedly semi-amateurish conditions in the socialist East. Similarly, in the 1980s, virtuosity was not an outmoded model for Polish pop-rock musicians, but an ideal still to be reached.

\section{Music stardom on Polish screen}

Representations of artists on the western screen often emphasize their exceptional qualities, genius, conflict with the external world and misfortune, as opposed to the historical circumstances under which they developed their art (Custen 1992; Tibbets 2005). Griselda Pollock (1980) summarises this approach as "psycho-biography" and mentions films about Vincent van Gogh as encapsulating it. Pollock is critical of psychobiographies, and advocates a greater emphasis on the relationship between artistic production and social, economic and political circumstances under which the artist operates. Psycho-biography also dominates western films about rock stars. Lee Marshall and Isabel Kongsgaard argue that,

rather than being seen as mere entertainers, or as one of a collective, rock stars became understood as highly individualised, self-expressive artists. A particular kind 
of rock-star persona began to emerge that reflected many of the characteristics of nineteenth-century bohemians: defying conventions, excessively engaging with sex and drugs to open the "doors of perception", demonstrating an unusual sensitivity and fragility, disdainful of those who "sell out", and so on. This bohemian stereotype has been a staple of popular music stardom ever since, right up to contemporary artists such as Amy Winehouse. (2012: 348).

This also affects the choice of portrayed stars. Similarly as in films about visual artists, where the unhappy and misunderstood painter van Gogh is a model, films about musicians are more likely to be about Mozart, Chopin, John Lennon or Amy Winehouse than Johann Sebastian Bach or Paul McCartney.

However, if we consider representation of artists in films made under the conditions of state socialism, we observe a different approach, as if the filmmakers responded to Pollock's call to move away from "psycho-biography" into what can be called "sociobiography". In such films artists are not severed from history but fully integrated into it. This is especially the case in films made during the hegemony of socialist realism, when filmmakers were required to focus on a typical (wo)man. "Typical" in this context does not mean "average", as put by Georgii Malenkov:

The typical is not that which is encountered most often, but that which most persuasively expresses the essence of a given social force. From the Marxist-Leninist standpoint, the typical does not signify some sort of statistical mean... The typical is the vital sphere in which is manifested the party spirit of realistic art. The question of the typical is always a political question. (quoted in Groys 1992: 51-52).

In practice, the typical character of socialist realist art was expected to be above average and synthesize the most important aspects of his or her times, like a perfect prism, refracting the salient features of the current political and social situation. The character was also meant to show others a new direction, either through fighting or work, undertaken for the benefit of the collective. Such views were presented in the seminal book about biography in the Soviet Union, Rostislav Yureniev's Soviet Biographical Film, published in 1949. Its author suggested that the protagonist of a biopic should be a great man and progressive activist, whose achievements the audience would like to imitate. Furthermore, the screen biography should foreground the historical meaning of the work and life of the famous individual, and therefore its author should concentrate on their social dimension, at the expense of depicting his or her private life (cited in Toeplitz 1952: 118).

Although socialist realism was promoted, even enforced in all European countries which adopted state socialism, this ideology was coloured by or blended with some local specificities. In Poland it was (Polish) Romanticism. This artistic current, arguably the most important paradigm in Polish culture, was born in the end of the eighteenth century, when Poland ceased to exist as an independent state, being partitioned between its mightier neighbours: Russia, Prussia and the Habsburg Empire. During this period artists 
were endowed with a mission to preserve Polish language, culture and national identity and to encourage their countrymen to strive to regain their statehood. A Polish Romantic artist (in contrast to most of his foreign counterparts) was less concerned with selfexpression and more with giving a voice to the community and engendering recipients of his work with a sense of responsibility for their homeland (Janion 1975). This also affected the understanding of an artist's "authenticity" - it was measured less by his or her resistance towards the commercial culture industry, and more by his or her opposition towards oppressive political authorities. The socialist realist and Polish Romantic approaches to artists have much in common, as both prioritize artists' service to the community. The difference is that in the Romantic discourse the privileged community is that of the nation, in socialist realism that of proletariat.

The seminal example of a Polish biopic which followed the precepts of socialist realism, while also trying to incorporate Romantic ideas was Mtodość Chopina ("The Youth of Chopin", 1952) by Aleksander Ford, the most prestigious film about a musician made in Poland during the state socialist period. Ford depicts Chopin as a young revolutionary, who fights against the Tsarist rule, which is both colonial and class oppression, and revolutionizes music (Mazierska 2004: 257-261). Other Polish and Eastern European biopics of musicians, made after the Second World War and especially in the 1950s, when socialist realism had a hegemonic position, followed a similar formula, for example Warszawska premiera ("Warsaw's Premiere", 1950), directed by Jan Rybkowski, about Stanisław Moniuszko, arguably the second greatest Polish composer of the pre-modern epoch, after Chopin.

Films about popular musicians started to be made in Poland in the 1960s, when socialist realism lost its hegemonic position and the 1980s saw an upsurge of films on this subject, reflecting the rock mania pertaining to this period (Pławuszewski 2015). Many were merely recorded performances of specific stars, but the most ambitious of them engaged with the Polish Romantic take on the social role of Polish musicians. Despite the fact that state socialism collapsed in Poland and Eastern Europe at large in the end of the 1980s, the same overall tendency can be found in films about musicians produced in post-communist Poland, namely a greater emphasis than in the West on historical circumstances and the artist's engagement in a wider political life.

However, while in the late 1940s and 1950s filmmakers went to great lengths to demonstrate that Polish musicians were proto-socialist revolutionaries, fighting against the oppression of the lower classes by capitalists and other reactionary forces, post-1990 the focus is on their patriotism, which often means being anti-communist. Accordingly, Chopin as a Polish patriot is at the centre of Chopin - pragnienie miłości ("Chopin Desire of Love", 2002), directed by Jerzy Antczak (Mazierska 2004: 261-67). Similarly, the recent film about Czesław Niemen, arguably the greatest rock star in Polish history, Sen of Warszawie ("Dream about Warsaw", 2014), directed by Krzysztof Magowski, underscores the hardship Niemen suffered under the communist regime and his patriotism. His attachment to his homeland is conveyed by the very title of this film, taken from one of the most popular songs in Niemen's repertoire, in which the singer expresses 
his love for Poland's capital and thus Poland at large. In the recent television series Anna German (2013), about a singer popular in the 1960s and 1970s, politics also plays a significant role. An example is including in its narrative a KGB officer who is in love with the singer's mother, despite the fact that such a person did not appear in her life.

In this context, it is worth mentioning that the two films I am considering in this article were made in a transitional period, when the state socialist system was crumbling, but the new ideologies of the post-communist period had yet not crystallized. A large part of Polish production of the 1980s shows skepticism about the ideas that had informed Polish politics and culture from the end of the eighteenth century, including Romanticism ${ }^{2}$. This might be a reason why, as I will argue, in the two films Maanam does not suit either the model of the artists as socialist revolutionaries, or the idea of artists as patriots.

Western biopics try to convince viewers that they present the real life of artists. Marshall and Kongsgaard draw attention to various techniques, which are meant to produce the effect of verisimilitude, such as voiceovers or involving the artists themselves, their families or close collaborators (2012: 354-355). In Poland such authenticating techniques were of less importance during the socialist period because, as explained, there truth was understood not as "sticking to the facts", but as revealing a deeper meaning of the artist's place in the history of his or her community, which might require neglecting or circumventing historical accuracy. In the post-communist period, however, the "truth" understood as sticking to the facts gained in significance. For example, the scriptwriters of Chopin-pragnienie miłościboasted about the large number of documents they sifted through to reach the "true Chopin" (cited in Śnieg-Czaplewska 2002: 30). Much was also written about the historical reliability of The Pianist (2002), Roman Polanski's film about the Polish Jewish pianist Władysław Szpilman. On this occasion such a claim was based both on its literary source, Szpilman's wartime memoirs and the similarity between the biographies of Polanski and Szpilman, with both being Holocaust survivors.

\section{Maanam as moral purifiers in Wielka majówka}

Krzysztof Rogulski, the director of Wielka majówka, does not easily fit into any recognizable paradigm of Polish cinema and his trajectory is somewhat atypical, because rather than moving from documentary to fiction cinema, he started with documentary films, made two fiction films, of which the second was Wielka majówka, to return to documentary filmmaking and occasionally to what is known in Poland as 'televised theatre': a hybrid between a television production and a theatre play. Post-Wielka majówka Rogulski's profile was low, despite his film being an instant hit. Why it failed to launch his career might be explained by the time it was made, shortly before the imposition of martial law in Poland in December 1981. After this, many Polish filmmakers moved abroad or stopped making films altogether. Rogulski belonged to the first category. He tried to continue his career in France, but with only moderate success. Wielka majówka has remained his greatest achievement. Although it is not linked to any 
wave, it shares some characteristics of the Cinema of Moral Concern, a movement dominating Polish cinema in the second half of the 1970s, until the imposition of martial law, due to its focus on an idealistic young man, contrasted with the corrupt society around him (Dondziłło 1982).

Wielka majówka, which is based on a true story, presents the adventures of two young men of modest background. Sixteen-year old Rysiek runs away from a borstal-cumorphanage to his father who rejects him on the ground of being unable to support him financially. Hungry, Rysiek breaks into a villa somewhere in the provinces and finds there, hidden in a fridge, a million Polish zloties. With this money Rysiek travels to Warsaw where he meets Julek, a man in his twenties, who pretends to be a sailor, although he is really a drifter, living in a provincial town without a stable occupation. The two men decide to spend their money on their titular "big picnic". They buy expensive clothes, a large convertible car and stay in Victoria, the most luxurious hotel in Warsaw. The exploits of the two friends allows Rogulski to create an image of Polish society in the final stage of state socialism as built on economic and social contrasts. On one hand, there is an impoverished province, where parents cannot support their children and there is nothing to do. On the other hand, we find an affluent and cosmopolitan Warsaw, with foreign guests served by high-class prostitutes. However, money rules everywhere. Almost everybody wants to make business and the unofficial economy thrives. Foreign currency has an almost magical value and some places are reserved only for foreign guests, rendering Poles second-class citizens in their own country. In this world the norm is pretending to be wealthier and worldlier than one really is.

The adventures of Rysiek and Julek take place in the close proximity of Maanam and to the accompaniment of its music, both extradiegetic and diegetic. Wherever they go, they encounter the band playing or just appearing as if out of nowhere. For example, when they run through the centre of Warsaw, Maanam has a concert opposite the Central Department Store (Domy Centrum), observed by a crowd of people. Rysiek also attends Maanam's recording session and dances when listening to their song "Oddech szczura" ("Rat's Breath"). There is a particular rapport between Rysiek, who is the more idealistic and naïve of the two, and Kora. She is like a good fairy, appearing when he is in trouble. For example, when Rysiek meets Julek with his posh girlfriend Agnieszka, embarrassing Julek, who pretends to be wealthier than he actually is, Kora approaches Rysiek, giving the impression that they know each other well. Their encounter changes the dynamic of the situation by suggesting that Rysiek, who has such stunning friends as Kora, must be "somebody". The fairy-tale character of Maanam is most obvious in the last scene of the film, when Rysiek and Julek are tried in court for theft. When the prosecutors present a long list of accusations, the two young men leave the court to find Maanam again, this time travelling in the back of a lorry with their instruments. They board a vehicle which is followed by another one, carrying a giraffe, seeing which fulfils Rysiek's greatest dream. This last scene has a surreal character, reflecting the place where the two friends would like to find themselves, far away from 'real socialist' Poland of the 1980s. 
By linking Maanam with the two provincial fugitives, Rogulski underscores the utopian character of Maanam's music, which is also conveyed by inclusion in the film of the paintings of Henri Rousseau. In the film Maanam stands for a pure world, which cannot be spoilt by money and lies, in which the corrupted 'adult world' indulges, rather than any specific political option or ideology. This is also revealed by the songs chosen for the film, such as "Ta noc do innych jest niepodobna" ("This Night Is Unlike Any Other Night", 1981), played several times in the film, and "Oddech szczura". These songs point to the band's ideology of living for the present, yet being removed from everyday reality, as if existing in a parallel world. This is also the way Rysiek wants to live. For this reason, it is difficult to imagine either of the two other most popular rock bands of the 1980s, Perfect and Republika, in the role in which Rogulski cast Maanam, because they were too anchored in Polish reality. Although Maanam in Wielka majówka is close to ordinary people, its magic is preserved. This is achieved by making the band communicate almost exclusively through music rather than dialogue. One of the reviewers compared the role played by Kora to that of a mime (Dolińska 1981). Moreover, the band is located outside the course of action; not unlike the chorus in an ancient play, which affords it special dignity.

In western biopics musicians are also positioned on the margin of society, but at the centre of the diegesis. On this occasion, the musicians are off-centre in both senses: disengaged from the social reality and from places occupied by the main characters. In my opinion, this reflects and adds to the sense of magic exuded by Maanam and its female star especially.

\section{Maanam as (non)Romantics in Czuję się świetnie}

Czuję się świetnie was the debut feature of Waldemar Szarek, who subsequently became a prolific, yet unremarkable director, oscillating between different genres, such as comedy, teenage film, as well as documentary, without specializing in any of them. Extensive use of music and interest in famous people is their common feature; in this respect Czuję się świetnie is a typical Szarek's film. It can be described as the first attempt at a rock biopic in Polish cinema, namely the first film devoted to specific real rock musicians in its entirety and purporting to unearth a deeper meaning of its life and artistry. Most likely Szarek was encouraged to make a film which would be "out of the box". This can be deduced from it being produced by the Karol Irzykowski Film Studio, which was set up in 1981 to allow recent graduates from the Łódź and Katowice Film Schools to make experimental films as an alternative to the bulk of Polish cinema of this period which took a turn towards more commercial production.

If we use the effect of verisimilitude as a criterion of categorizing the material used in a biopic then we can divide Szarek's film into three parts. One consists of fragments of Maanam's concerts. This part comes across as a straightforward documentary and fills the largest part of I Feel Great. The film begins with the image of a crowd of young people smashing a gate, most likely to go to Maanam's concert, despite the police trying to 
prevent them. This impression is confirmed by an image of the feet of a drummer, probably Paweł Markowski, playing the beginning of one of the band's songs. Such an image captures two important aspects of Poland in the first half of the 1980s: the great popularity of rock, as demonstrated by the proliferation of large rock festivals and the omnipresence and impotence of the police. In this sense the film is not different from western "rock films", which typically present the political authorities in bad light. Here policemen not only ensure that order is maintained during the events, but also stand for the "police state", as Poland was regarded during this period. We also overhear a conversation between the fans, in which one young man asks another, tackled by the police, how he feels and gets the answer "I feel great". This response provides the title of the film. The other source of the film's title is the title of one of Maanam's songs. Having the same words uttered both by band and fans creates a "fit" between musicians and audience. At the same time, these words are imbued with irony, given that the first half of the 1980s was marred by food rationing, long queues for basic commodities and political turmoil. However, such a "political rollercoaster" has always been favoured by punk.

The remaining scenes from the concerts are made according to the same formula, typical for "rock films", of which Woodstock (1970), directed by Michael Wadleigh, is a notable example, oscillating between live performances, usually shown in close-up, and the audience, often behaving in an unruly way, overcoming the obstacles separating them from the stage. In this category I will also include the early shots when we hear voices off screen reading fragments of letters of Maanam's fans, first against images of the skyline of an indistinct city, dominated by skyscrapers. Most likely this footage was taken in Warsaw, but the idea is to present a "universal city". Then the camera visits some hotel rooms with sleeping people, finishing with Kora and her husband Marek in bed. Voiceover and quotations from letters are one of the devices which give the impression of verisimilitude (Marshall and Kongsgaard 2012: 354-355) in this case read by members of the band. The testimonies of the fans overlap, giving the impression that they ultimately constitute one voice. The fans reveal their love of the band and of Kora especially, based on the perceived difference between the lives of these young people and the life that, in their imagination, Kora leads. Their lives are provincial, monotonous and empty, Kora's life is metropolitan and full of adventure and therefore a source of inspiration for the fans. Listening to Maanam's music allows their fans to transcend their situation and feel as if they are in a different place, not unlike in Wielka majówka, where the music of Maanam also signified adventure and utopia.

The second type of material shows Maanam when they do not give concerts, in private or semi-private situations. The first episode belonging to this category presents Kora with another member of Maanam in a fun fair, on a rollercoaster. The metaphorical meaning of this image is easy to decipher: the band lives a fast, exciting and possibly dangerous life. We also see the Jackowskis talking directly to camera about their lives, giving a press conference and travelling in a bus on their concert tour. We expect that these episodes will also show the truth, but on occasions one gets an impression that they were 
staged and that the members and Kora especially, played to the camera, as suggested by some unusual, whimsical or plainly absurd questions and answers.

This material tests the hypothesis that the band's life is more exciting than that of ordinary Poles, as stated in the letters from fans, suggesting that this is not the case. We get a sense that Maanam lead a fast, but not necessarily a colourful or affluent life. For example, during a press conference, when asked about Maanam's foreign trips to cities such as West Berlin and Copenhagen, Kora admits that she had no time to see them or buy presents for her children because her time was taken up by work. We also see the band traversing a provincial rather than metropolitan Poland. The hotels where the musicians stay come across as shabby and they travel in a hired bus, which is spacious and quite comfortable, but also brings to mind the way the majority of Poles travelled in the 1980s. There are no images of Maanam on the planes or performing abroad. Such a depiction of "working musicians" is common in biopics, contrasting their on-stage appearance with the unglamorous reality of their life offstage. In Poland in the first half of the 1980s this motif had an additional context, resulting from the special position of rock in this period, the widespread rejection of the ideological tenets of state socialism and the early neoliberalization of the Polish economy. All these factors led to an opinion, expressed by the rock stars and their fans, that they got less than they deserved, as presented, for example, in the documentary Beats of Freedom (2009), directed by Leszek Gnoiński and Wojciech Słota. Complaints about financial status were common among Polish stars and Maanam was no different from this perspective. The juxtaposition of the shabby hotels and thousands of young people attending Maanam's concerts could be interpreted as a means to expose the injustice of the state socialist culture industry and its economy at large.

Some reviewers argued that Szarek tried to expose Maanam's banality and pomposity, as when we hear Kora saying that she had an unhappy childhood and turned to books to isolate herself from her environment or that their music gives meaning to the lives of their fans (Klimczak 1985). Another possible means to undermine Maanam's intellectualism was including Kora's lyrics, read by her off-screen. Inevitably, devoid of music, they lose much of their poetry and sound fake. If it was indeed Szarek's intention to prove that the rock star did not deserve their fans' devotion, he followed in the footsteps of probably the most famous Polish film (documentary) about a rock star prior to Czuję się świetnie, Sukces ("Success", 1968) by Marek Piwowski, about Czesław Niemen. Sukces shows the then greatest Polish pop star as self-important, opinionated and banal, hence failing the ultimate test of a rock star's value - that of authenticity (Mazierska 2016: 18-22). However, while Piwowski succeeded, leading to Niemen's accusation of defamation and demand that Success be withdrawn from distribution, Szarek failed. This happened either because, unlike Piwowski, Szarek was unable to capture on camera the embarrassing moments effectively, being outsmarted by the Jackowskis who came across as more natural and modest than Niemen in Piwowski's documentary. Another possible explanation is that, as one reviewer suggested, he tried to appeal to two types of audiences: Maanam's fans and those (allegedly more mature and sophisticated viewers) 
who looked with a caustic eye at the Polish rock phenomenon (Pawlicki 1985). It is also possible that he was unsure if he wanted to offer a eulogy or a satire on Maanam or changed his mind in the course of assembling the material, perhaps at the request of the censors. However, censorship was quite light in this period and the Irzykowski Studio at that time offered filmmakers much artistic freedom.

The third type of material used in Czuję się świetnie is clearly fictional. One example is the extended episode of a ceremony naming a school after Kora and a Polish literature lesson when teenagers are asked to analyse the lyrics of "Czuję się świetnie". These episodes suggest a connection between Maanam and Polish Romantic poets as they, most importantly Adam Mickiewicz and Juliusz Słowacki, used to be the most frequent patrons of Polish schools. Moreover, in one part of the lesson the teacher claims that, like these poets, Kora, who is the protagonist of Czuje się świetnie, puts herself above the crowd being the one who is standing, while the crowd is lying down, lazy and passive. Such a comparison is far-fetched and most likely was meant to deride those who saw in the Polish rockers the descendants of Mickiewicz and Słowacki. However, if Szarek's intention was to mock Maanam, it backfired, because it is not the members of Maanam who assume the position of the "new (Polish) Romantics", but the authorities who in the film try to integrate them into the Romantic discourse and most likely render Polish rock innocuous $^{3}$. It is possible that this part is a satire on the authorities who attempted to make peace with the rebellious rockers. Again, the reviewers noticed that the result of these fragments were ambiguous and they did not work well, not being funny (Lenard 1985; M. D. 1985; Pawlicki 1985). Even less successful is another episode when the band takes part in the staging of a Shakespeare poem. It is difficult to elucidate its meaning, except that it suggests (not unlike the episode of the Polish literature lesson) that Maanam might harbour some high-art ambition. But the authorial intention is again unclear. Did Szarek want to mock the band and Kora especially for seeing themselves as descendants of Shakespeare or did it concern rather rock journalists? Again, reviewers were unsure.

The fictional inserts suggest that Szarek attempted to make a mockumentary ${ }^{4}$. However, filmmakers using this genre tend to preserve a consistent tone in their films, which are fictional, but give the impression of being documentaries (Hight 2008) through using documentary conventions. The purpose of making mockumentaries is usually to ridicule a specific social phenomenon and as its name suggests, to mock documentary (and documentarists) by demonstrating that the documentary effect is a matter of using specific conventions (such as voice-over or camerawork) rather than representing reality truthfully. By contrast, Szarek's film lacks a consistent tone, oscillating between a serious documentary, fake documentary and a fictional film and it is not obvious what Szarek intended to mock in his film: the band itself, the "Maanam phenomenon", the entire rock culture in Poland of this period or the Polish obsession with Romanticism (Królak 1985; Lenard 1985; M. D. 1985; Pawlicki 1985). Whatever was the ultimate motive of shooting Czuje się świetnie, the film reflects a somewhat schizophrenic attitude of the political authorities and the part of cultural elites toward rock music in the 1980 s by, on the one 
hand, acknowledging the role it played in the lives of young people and willing to support it for the sake of educating and pacifying the youth, and, on the other hand, expressing frustration at its dislocating high art from its privileged position in the country's culture.

\section{Conclusions}

Although the presence of Maanam in the two films discussed in this article is the main reason for their lasting popularity, they do not try to show us the "real Maanam". Wielka majówka attempts to "spiritualize" the band, most likely to justify their role in the narrative as offering the characters a journey to a different reality from one rendered as completely unacceptable. The second film uses various de-authenticating techniques to put a question mark over its character as a documentary and a biopic, most likely to show sophistication through making the viewer question what type of film is he or she is watching, which was appreciated in Piwowski's film about Czesław Niemen. Together, they show that while in the 1980s filmmakers in Poland recognized the commercial potential of using rock music and rock stars in films, they were not fully aware of the advantages of making biopics according to the western formula of "telling the truth" or did not care about these advantages. This can be explained by less commercial pressure exerted by Eastern European filmmakers in comparison with their western counterparts, and the spirit of experimentation which had flourished in the somewhat chaotic 1980s Poland. However, after the fall of the Berlin Wall, when the pressure to make profitable films in Eastern Europe increased, biopics and other types of films that use popular music extensively, started to look more "western". Ironically, many of these films use Hollywood conventions to convey nostalgia for music consumed and produced during the time of state socialism. However, discussing these films would exceed the scope of this article.

\section{Endnotes}

1 The name "Maanam" was derived from first names of Jackowski and Kurtis, Marek and Milo.

${ }^{2}$ In the 1980s the most fashionable political position taken by the musicians was that of the opposition against any political system or the System (Brzozowicz 2010:19). In this sens, Polish rockers can be seen as followers of the western 1960s youth counterculture, which was resolutely against all parties and movements.

${ }^{3}$ During the history of Polish rock under state socialism the authorities changed their position considerably, first seeing rock as an enemy of the state and then as a way to reach to the young people. Hence, they tried to make peace with the rebellious rockers or even pampered them. The shift happened in the 1970s, under the regime of Edward Gierek.

${ }^{4}$ Szarek was probably the first Polish filmmaker to dabble with mockumentary while making films about rock music. However, before him, in 1983, Polish Radio Three programme broadcast a mockumentary about band Republika, titled Odlot (Trip), produced by Zbigniew Ostrowski in 
cooperation with the band's leader, Grzegorz Ciechowski, which proved very successful (Fortuna 2016). Possibly Szarek was inspired by this programme.

\section{References}

\section{Bibliography}

Brzozowicz, G. 2010. Punk vs. System. In Beats of Freedom - Zew wolności. Warszawa: Narodowe Centrum Kultury: 16-20.

Butrym, M. 1985. Dola idola. Warszawa: Młodzieżowa Agencja Wydawnicza. Custen, G. 1992. Bio/pics: How Hollywood Constructed Public History. New Brunswick: Rutgers University Press.

Dolińska, E. 1981. Konsumowanie cudzego nawisu. Film 48: 14.

Dondziłło, C. 1982. Fantazja i pieniądze. Film 2: 16.

Fortuna, P. 2016. Perverse Imperialism: Republika's Phenomenon in the 1980s. In E. Mazierska. Ed. Popular Music in Eastern Europe: Breaking the Cold War Paradigm. London: Palgrave: 283-301.

Groys, B. 1992. The Total Art of Stalinism: Avant-Garde, Aesthetic Dictatorship, and Beyond, trans. Charles Rougle. Princeton: Princeton University Press.

Haenfler, R. 2015. Punk rock, hardcore and globalization. In A. Bennett and S. Waksman. Eds. The Sage Handbook of Popular Music. London: Sage: 278-295.

Hight, C. 2008. Mockumentary: A Call to Play. In T. Austin and W. de Jong. Eds. Rethinking Documentary: New Perspectives, New Practices. Berkshire: Open University Press: 204-216.

Hučková, J. 2015. Opowieści naocznego świadka. Kino pomiędzy wiosnami Solidarności. In M. Hendrykowska. Ed. Historia polskiego filmu dokumentalnego. Poznań: Wydawnictwo Uniwersytetu im. Adama Mickiewicza: 361-469.

Inglis, I. 2007. Popular music history on screen: the pop/rock biopic, Popular Music History 2 (1): 77-93.

Jackowska, O. and K. Sipowicz. 1992. Kora: Podwójna linia życia. Warszawa: Agencja Piękna.

Janion, M. 1975. Gorqczka romantyczna. Warszawa: Państwowy Instytut Wydawniczy. Klimczak, L. 1985. Kora, Kora, Kora... Ekran 8:16.

Królak, S. M. 1985. Wszystko bez sensu? Kino 7: 13-14.

Laing, D. 1985. One Chord Wonders: Power and Meaning in Punk Rock. Milton Keynes: Open University Press.

Lenard, J. 1985. Maanam Story? Stolica 18: 18.

Marshall, L. and Kongsgaard, I. 2012. Representing popular music stardom on screen: the popular music biopic. Celebrity Studies 3 (3): 346-361.

Mazierska, E. 2004. Multifunctional Chopin: the representation of Fryderyk Chopin in Polish films. Historical Journal of Film, Radio and Television 2 (24); 253-268. 
Mazierska, E. 2016. Production, Consumption, Power, and Humor in the Films of Marek Piwowski. Journal of Film and Video. 68 (2): 14-28.

M. D. 1985. Kapłanka rocka w podróży. Kamena 6: 10.

Patton, R. A. 2011. Screamed Poetry: Rock in Poland's Last Decade of Communism. PhD. University of Michigan, Ann Arbor, Michigan.

Pawlicki, M. 1985. Piłowanie gałęzi. Film 12: 9.

Pęczak, M. 2010. Co mógł rock. In Beats of Freedom - Zew wolności. Warszawa:

Narodowe Centrum Kultury: 38-40.

Pławuszewski, P. 2015. Kino mocnego uderzenia: Polsk muzyka rockowa w polskim kinie dokumentalnym lat 60. i 70. Kwartalnik Filmowy 91: 105-120.

Pollock, G. 1980. Artists, Mythologies and Media - Genius, Madness and Art History. Screen 21 (3): 57-96.

Śnieg-Czaplewska, L. 2002. Romantyczna gorączka, Viva 6: 28-32.

Tibbets, J. 2005. Composers in the Movies: Studies in Musical Biography. New Haven: Yale University Press.

Toeplitz, J. 1952. Młodość Chopina. Kwartalnik Filmowy, 5-6: 102-15.

Vidal, B. 2014. Introduction: the biopic and its critical contexts. In T. Brown and B. Vidal Eds. The Biopic in Contemporary Film Culture. London: Routledge: 1-32.

Zieliński, P. 2005. Scena rockowa w PRL-u: Historia, organizacja, znaczenie. Warszawa: Trio.

\section{Discography}

Maanam. 1981. "Boskie Buenos", Maanan, Wifon, Poland.

Maanam. 1981. "Czuję się świetnie”, Maanam, Wifon, Poland.

Maanam. 1981. "Oddech szczura", Maanam, Wifon, Poland.

Maanam. 1981. "Ta noc do innych jest niepodobna", Och ten Hollywood, Tonpress, Poland.

Maanam. 1982. "Jest już późno, piszę bzdury", O!, Pronit, Poland.

Maanam. 1983. "Nocny patrol", Jako/Polton, Poland.

\section{Videography}

Anna German. 2013. Dir. Waldemar Krzystek, Aleksandr Timenko, Star Media.

Beats of Freedom - Zew wolności. 2009. Dir. Leszek Gnoinski, Wojciech Slota, IAM Bohater Roku . 1987. Dir. Feliks Falk, Perspektywa.

Chopin - pragnienie miłości. 2002. Dir. Jerzy Antczak, Skorpion Art.

Czuję się świetnie. 1984. Dir. Waldemar Szarek, Studio Filmowe im. Karola Irzykowskiego.

Mtodość Chopina. 1952. Dir. Aleksander Ford, WFF Lodz.

Sen of Warszawie. 2014. Dir. Krzysztof Magowski, Warta-Film.

Sezon na bażanty. 1986. Dir. Wiesław Saniewski, Oko.

Sukces. 1968. Dir. Marek Piwowski, Wytwórnia Filmów Dokumentalnych. 
The Pianist. 2002. Dir. Roman Polanski, R.P. Productions, Heritage Films, Studio Babelsberg, Runteam.

Warszawska premiera. 1950. Dir. Jan Rybkowski, Film Polski.

Wielka majówka. 1981. Dir Krzysztof Rogulski, Silesia.

Woodstock. 1970. Dir. Michael Wadleigh, Wadleigh-Maurice. 